Article received on 31st May 2011

Article accepted on 18th November 2011

UDK: 78.071.1 Стефановић И.

78.083 .4

\author{
Mirjana Veselinović-Hofman* \\ University of Arts in Belgrade \\ Faculty of Music \\ Department of Musicology
}

\title{
AIR, GROUND AND WATER OF A CAPITAL OF SILENCE IVANA STEFANOVIĆ'S RADIOPHONIC EPIC POEM METROPOLA TIŠINE/STARI RAS [METROPOLIS OF SILENCE/OLD RAS]**
}

\begin{abstract}
In her creative opus, Ivana Stefanović uncovers the sounds of the natural environment, in their full richness and stratified connotations. The ambiant sounds she uses, have a special meaning in her work, particularly when they act poetically and aesthetically as designators, functionalized as aspects of silence. And even more so when they demonstrate a culturological, archaeological dimension of silence. This text examines the interference of the silence of a historical and cultural ambiance with the inner, perceptional silence of a personal artistic meditation, which is pointed out by Ivana Stefanović's radiophonic epic poem Metropola tišine / Stari Ras (1992).

Keywords: Ivana Stefanović, Stari Ras, silence, samples, acoustic signposts, acousmatic sound, object, radiophonic processing

\footnotetext{
* Author contact information: mvesel@eunet.rs

** This research was carried out within a theme The Aspects of Musical Silence in Serbian Postmodern Music, as part of the scientific project of Matica srpska, supported by the Ministry of Education and Science of the Republic of Serbia.
} 
Veselinović-Hofman, M.: Air, Ground And Water Of A Capital Of Silence... (24-34)

Апстракт: У свом стваралачком опусу, Ивана Стефановић разотркива амбијенталне звукове у свом њиховом богатству и слојевитим конотацијама. Амбијентални звукови које користи имају посебан смисао у њеном стваралаштву, поготову онда када поетичко-естетички дејствују на означитељском нивоу, функционализовани као аспекти тишине. И при томе поготову онда када предочавају једну културолошку, археолошку димензију тишине. У овом тексту реч је о интерференцији тишине једног историјско-културалног амбијента са унутрашњом, доживљајном тишином ауторкине личне уметничке медитације, истакнутој у радиофонској поеми Метропола тишине / Стари Рас (1992).

Кључне речи: Ивана Стефановић, Стари Рас, тишина, узорци, звучни путоказ, акузматички звук, објект, радиофонска обрада

Listening to the sounds of nature implies to a great extent their simultaneous decoding, since those sounds have always represented something more than just pure acoustic events to human beings. Especially to those people whose elementary survival depended on the will of nature: farmers, fishermen, sailors etc. For them, the types, ranges and intensities of sounds of rain, wind, thunder or waves, for example, always were (and still largely are) kinds of 'soundposts' ${ }^{1}$ : a message, 'advice', a direction, a warning, a threat, a prophesy... Similarly, the other sounds of the natural environment, those originating from human settlements built within it, which exist there perhaps only 'incidentally', neglected, solitary or, on the contrary, as incarnations of the environment in question, can contain various meanings and messages.

In her creative opus, Ivana Stefanović uncovers those sounds in the full richness and stratified connotations of the ambiant sounds she uses, and which in her creative work have a special meaning, particularly when they act poetically and aesthetically as designators, functionalized as aspects of silence. And even more so when they demonstrate a culturological, archaeological dimension of silence. ${ }^{2}$

It is namely the silence of more or less preserved historic and cultural monuments, the silence which means the absence of the times when the monuments were built and the life whose centre they were. By that absence of their former reality, by that silence of their past and former life, the monuments have remained to persevere as kinds of archaeological, culturological witnesses to that reality and that life, in all the following ages with different social, political and economic cir-

\footnotetext{
${ }^{1}$ Peter Englund, 'O istoriji tišine' ['Tystnadens historia'], in: Male istorije [Small Histories]. Edited and translated from Swedish by Ljubiša Rajić, Belgrade, Geopoetika, 2009, 96.

${ }^{2}$ Cf. Mirjana Veselinović-Hofman, 'Reflection on Silence', in: Tatjana Marković \& Vesna Mikić (eds.), (Auto)Biography as a Musicological Discourse, Belgrade, Department of Musicology - Faculty of Music, University of Arts in Belgrade, 2010, 256-265.
} 
cumstances. Therefore, the entire ambiance around them, realistic and contemporary, is stratified by the past, and its reception implies an unlimited range of content and emotions. Being deeply individualistic in character, that reception can include the revival of one's own knowledge about some particular historical events, related to specific archaeological remains and relics and, generally, monuments which persevere in that ambiance 'breathing in' its air nevertheless; it can include imagining, conjuring up the visions of those events in one's own consciousness; thinking about them as pointers to many current issues, maybe even issues about some 'eternal' burden of fate of a particular nation, a specific region. Also, the reception can be, e.g. based upon associations with various events and phenomena, which need not be related at all to the area in question in any immediate, factual way. On the contrary, they can stand in very distant, mind-produced relations with some other historical and cultural spheres. The ranges of inner reception, the experiences of a history-laden ambiance are therefore unlimited. Those are the ranges of free meditative communication with that ambiance, performed in personal inner silence, as well as of potential communication with everything which has left the traces of its total former configuration and constellation within that ambiance; with the traces of what the ambiance once was, what it witnessed or what it experienced on the journey to the present moment of our immediate contact with it. Of course, if one's knowledge about the past of a certain ambiance, its historical experience and historical destiny is greater, the closed, withdrawn, quiet reflective and emotional relationship with it will be more substantial and deeper, and the possible symbolic communication between its recipients more complex. Particularly between those who perceive that historical space immediately, becoming absorbed in it in a creative way as well, thus shaping their contemplation by a work of art, and those who face that space in an indirect way, i.e. through the said work of art.

We could therefore say that here we have two kinds of silence that permeate each other. One is lived by monumental and archaeological sites carrying through the centuries the aura of their erstwhile worlds; the other is the silence of individual receptive responses, either directly to the silence of those locations or to its potential artistic transposition. If we should attempt to place these two kinds of silence within an appropriate section in the widest classification of the functions of silence, proposed within an integrated theory of communication, ${ }^{3}$ we would note that those two kinds of silence can be understood as a permeation of two types of silence which that classification designates as individually determined/negotiated. ${ }^{4}$

\footnotetext{
${ }^{3}$ Cf. Muriel Saville-Troike, 'The Place of Silence in an Integrated Theory of Communication', in: Deborah Tannen and Muriel Saville-Troike (eds.), Perspectives on Silence, Norwood, New Jersey 07648, Ablex Publishing Corporation, 1995, 3-18. Also cf. Muriel Saville-Troike, The Ethnography of Communication: An Introduction, Oxford, England, Basil Blackwell, 1982.

${ }^{4}$ Cf. Saville-Troike, 'The Place of Silence...', in op. cit. 16.
} 
Veselinović-Hofman, M.: Air, Ground And Water Of A Capital Of Silence... (24-34)

Within it, that is actually a kind of social-contextual silence, i.e. a socially indicative, contextual dimension of interactive silence. There are also the contemplative-meditative spaces of a deeply personal, non-interactive, non-exchanging silence. ${ }^{5}$

That interference of the silence of a historical and cultural ambiance with the inner, perceptional silence of a personal artistic meditation is strongly pointed out by Ivana Stefanović's radiophonic epic poem Metropola tišine/Stari Ras (1992).

Created in the decade when a brutal war had devastated the Yugoslav nations' community, the poem indirectly suggests a symbolic relationship between that aspect of our most recent history and a distant historical past, also governed by a fate of comprehensive annihilation.

The work is namely based on acoustic materials which the author recorded in the area of Stari Ras and the monasteries of Sopoćani and Crna Reka. Those are authentic sounds from those sites, which on one hand are functionalized in the composition as acoustic petrifications 'found' in the said area, and on the other, thanks precisely to that, they are functionalized also as kinds of acoustic signposts ${ }^{6}$ to the past of those sites.

Other than that, the recorded samples are used as the basic acoustic material of the work. During its shaping, they are subjected to radio technology, in the sense of the development and expansion of Pierre Schaeffer's musique concrète et acousmatique. The musical content of the composition is thus primarily supported by a material whose source for us is placed behind the 'screen' of the loudspeakers, but also to a sound produced by musical instruments and voice. That sound is in turn articulated within recognizable musical categories of melody, rhythm, time signature, harmony and is predominantly improvisational in nature.

The sound material during the radiophonic processing keeps the elements of the given site's authentic acoustics to the greatest possible extent. Often, however, those elements by themselves leave the impression as if they are the result of a certain electronic processing of the recorded material. ${ }^{7}$ Apart from that, the acous-

\footnotetext{
${ }^{5}$ Cf. ibid. $16-17$.

${ }^{6}$ The expression is understood in the sense Peter Englund uses it (Peter Englund, 'O istoriji tišine', in: op. cit. 96).

${ }^{7}$ In that sense, what is characteristic are the author's words about a sound image which appears for the first time somewhere between the $3^{\text {rd }}$ and the $4^{\text {th }}$ minutes of the work, and later around the $12^{\text {th }}$ minute (time references here, as well as later in the text, are given according to the recording of the work released on Ivana Stefanović's authorial CD - inner landscape / unutrašnji pejzaž, in: Zorica Premate (ed.), late $20^{\text {th }}$ century Serbian music CD series, Belgrade, SOKOJ CD 205, 1996): 'Postoji scena povlačenja konja (ili vola) uz brdo. Uvala je bila velika, čovek (ili ljudi) su vukli životinju, bili su vrlo udaljeni, jedva sam ih mogla videti kroz šumu,
} 
matic sound was used in the juxtaposition and superposition of the samples, but also in their juxtaposition and superposition with a traditionally produced and shaped musical sound. Also, one can note that the samples intersect in a specific manner. From the aspect of meaning, one of the most functional ways of placing them in a relationship like that is a kind of departure of a sample from its own acoustic traits towards the traits of another sample, hence it is as if these samples exchange their general acoustic traits with one another. In all the mentioned procedures, there are also spatial changes of acoustic layers, in the sense of their coming closer together or farther apart, or directional changes of the musical flow, but always with the general striving to keep the recorded material within its most characteristic properties.

Using the samples in the described ways, the composer treated them as pivots of the total dramaturgy of the work, both extramusical and musical. It means that the possibility of identification of a particular sound or 'family' of sounds has both a semantic and formal sense within the composition. Semantic because the possibility of such identification is the basis for representing and recognizing a particular setting dealt with in the work, which immediately suggests the possible directions of extramusical associations and thought processes during the reception of the work. The formal sense, on the other hand, is there because the recognizability of the samples plays the role of specific markers ${ }^{8}$ of the work's form.

For example, the first formal phase of the composition is populated by the acoustic events as designators of the ambiance of nature and open space. Most of these events can be recognized more or less precisely. ${ }^{9}$ That is the case with the barely audible 'rustling' of air, the rapid sounds of crickets, steps seemingly made over slippery and loose pebbles, the dense chirruping of birds; horses' stomping

ali su zvuci bili vrlo jasni i, mada razliveni u prostoru, utisak je bio da su blizu. Nije bio potreban nikakav dodatni "eho".' ['There is a scene of pulling a horse (or an ox) up a hill. The hollow was large, a man (or men) was hauling the animal, they were very far off, I could hardly see them through the forest, but the sounds were very distinct and, although scattered in the space, it seemed they were coming from close by. No additional "echo" was necessary.'] (From an electronic conversation with I. Stefanović, 26 ${ }^{\text {th }}$ January 2010).

${ }^{8}$ The term was taken from Boulez's terminology in the problem area of musical form. More in: Mirjana Veselinović-Hofman, Pred muzičkim delom. Ogledi o međusobnim projekcijama estetike, poetike i stilistike muzike 20. veka: jedna muzikološka vizura [Facing a Musical Work. Essays on Mutual Projections of Aesthetics, Poetics and Stylistics of the $20^{\text {th }}$ Century Music: a Musicological View], Belgrade, Zavod za udžbenike, 2007, 131-133.

${ }^{9}$ Our recognition of these events does not have to be 'absolutely correct', given that the only record of the Poem is the acoustic one, thus the analysis of the composition is not based on any kind of written score. Therefore, I hereby thank Ivana Stefanovic for the information on some sound sources she used in the Poem. 
and neighing; the sound of water, whose quality travels from descriptive and pastoral to conflicting and biting, and whose intensity rises all the way to the dominating acoustic force which soon, like a kind of sunken river, recedes to the depths of the earth, continuing to act 'somewhere beneath', invisible and inaudible; almost as a kind of 'proto-line' of the following formal layer within the same stage of the acoustic/musical flow. In that layer, the ambiance of open space is acoustically expanded and concretized by new contents as specific symbols of a village environment. The simple, quotidian and homely ones, where the distant calls of a male voice seem to draw the acoustic camera closer to the working rhythm of rural trades, personified by the sound of striking wooden objects. Thus, from the surroundings of 'pure' nature stretching near a village, which in turn seems to be fused with that lonely, almost primordial natural ambiance, a human voice "enters" the village, by drawing it nearer to the acoustic foreground, and by fitting it into the everyday, usual space of rural sound. Its part is also the sound of two shepherd's flutes, with two different melodies, ${ }^{10}$ which are mutually related by motive and articulation patterns of Serbian folk music present in them. The space of rural sound also contains the permeations and stratifications of these improvisational patterns with echoes of calling and/or acoustic symbols of village work, which from a certain point on are 'stitched through' with a female voice as a new sample. A short focusing on that voice treated in a soloist manner - followed by playing on the šargija, which seems to display 'the other parts' of elementary existence, in fact the necessary, complementary spiritual and creative dimension of basic human work and life - vaults the first formal stage of the work.

We could say that its two described waves, based upon the predominant recognizability of the concrete sounds of nature and the everyday village, are given with the purpose of a specific acoustic exposition of the work. At the same time, however, they are also given with the purpose of its specific semantic exposition, since these waves are based upon some of the 'eternal' designators of a Serbian village settlement.

The second formal stage (starting at 6 minutes and 42 seconds) of the work brings the condensed 'resume' of natural sounds represented in the first stage, followed by the sounds of everyday life personified by a shepherd's voice. It is introduced to an 'ether' of sounds made by various types of bells: cowbells which remind us of some late-afternoon return of the cattle from pasture, church bells,

\footnotetext{
${ }^{10}$ The author mentions that these 'dve različite melodije razdvaja prostor' ['two different melodies are separated by space']. 'Jedna je levo, druga desno. Sviraju Žorž Grujić i Ljuba Dimitrijević.' ['One is on the left, the other on the right. Played by Žorž Grujić and Ljuba Dimitrijević.'] (From the electronic conversation...)
} 
both as habitual and liturgically regular, but also in a distribution of a rhythmically striking motive which imposes itself ever more and conquers the acoustic space.

The next formal wave (from 8 minutes and 23 seconds) begins with a melody on the recorder. That melody leads to a new, more severe level of everyday life, where work rhythms, sounds of wood and metal, human voices, the sound of a falcon, ${ }^{11}$ rocks, ice breaking and knocking, the splashing of water, the neighing and stomping of horses... therefore, concrete nature and concrete life seem to confront something which gives the impression and presentiment of a muffled atmosphere of inevitability. A special dimension to that atmosphere is lent by church bells, which here seem to become a witness to that foreboding and destruction and conflict. Through that generally harsh acoustic configuration, a few preserved natural sounds and male voices break through, which now seem to be in a kind of warlike communication. These are actually the known village life and nature which in fact ceased to exist as we knew them, or at least they are not only what they were previously. They became a stage of struggle and calamity.

A soloist female voice (from 16 minutes onward) in its extensive performance of the folk song 'Soko bira gde će naći mira', ${ }^{12}$ - later joining the ambiance background of air and wind 'noises', distant thunder as both a natural phenomenon and a sign of struggle - is a new but short-lived chapter of the renewal of life, with the spiritual sources of Miloš Obilić's and Marko Kraljević's heroic histories. The elementary power of sound developing in several waves - which occasionally become distinct and resemble the scraping of metal, the striking of wood, the breaking of ice, forging and building, the clattering of a cart, work in circumstances of uncertainty, or rather the certainty of new devastation - is directed towards the extremely severe and harsh acoustic frame of the work as a complex developmental stage of its globally arched formal vault. The situation precedes a gradual transition into polyphonic male singing (from 24 minutes and 40 seconds onward), based on church intonations with the text 'Gospodi pomiluj' ['Kyrie Eleison'], and the appearance of a female voice. A nun speaks/'sings' her prayer hurriedly, recitatively, 'breathlessly', bringing possible consolation - 'čekam vaskrsenje mrtvih i život budućeg veka' ['I look for the resurrection of the dead, and the life of the world to come'] - which seems to transform into the power of the people and its voice. The recitative line alternates with it for a short while on its way to sinking to the acoustic base from where, as the vision of a possible light (or the presentiment of a renewed tragedy), the soloist cantabile of a female voice upon a male pedal note rises up.

\footnotetext{
${ }^{11}$ I. Stefanović provided the information that a sound which reminded us to a whistle several times in the composition is actually a falcon's scream.

${ }^{12}$ Information obtained from the author.
} 
The conclusion of that rich, semantically metaphorical developmental episode, which 'went through' the tragic destiny of an area and an ethnicity, through its way of life and survival in work and battle and song and the spirit of a heroic past and fate, is marked by a return to the ambiance of 'pure' nature. What follows is the epilogue which is thus dominated again by its sounds (from 29 minutes and 38 seconds onward). However, the focus now is solely on water. Water, which 'outlived' both the air and ground of the area; which, on one hand, surrendered to them in its acoustically recognizable form, but always provided power for them by the mystery of sunken rivers, transforming, when necessary, into the blows of unrelenting battle. Therefore the epilogue is 'ruled' by water in its wide range, in its various, graded forms: as a gentle shower, a downpour, a storm, a torrent of water ${ }^{13}$ which destroys, washes and rinses away everything in its path, but also irrigates... As a force of conspiracy, force of destruction, force of purification and force of renewal.

The basis upon which the presented formal-semantic dimension of a concrete acoustic material is realized in this composition is the understanding of sound in a double relationship with the object: as inseparable and as separable from the object it originates from.

As an inseparable part of the object, the concrete sound attests to the immediate presence of that object. In other words, it attests to the object which 'lives' there, in front of us, as the part of a certain ambiance, a part of reality which surrounds us at the given moment, as an object of our perception and immediate experience. In that sense, the concrete sounds present in this composition also serve as immediate pointers to the presence of the associated object related to a particular area; objects like insects, horses, a falcon, water, people, a hammer, an anvil, wood, metal, specific musical instruments... By that blending of sound and 'its' object, i.e. by the specific connection between the acoustic and the extraacoustic-associative, a specific ambiance is defined and presented. Therefore here we are talking about an ambiance which the author has visited and whose sounds she has recorded.

The other of the two mentioned relations between a concrete sound and 'its' object begins precisely with that recording. The author in fact separated that sound

\footnotetext{
${ }^{13}$ According to I. Stefanović's words, this is 'nekoliko minuta snimka jedne prolećne, planinske bujice' ['a few minutes' recording of a springtime mountain torrent']. 'Bujica je došla potpuno neočekivano, iznenada, dok sam šetala pored smrznute reke na Zlatiboru. Iznenada sam čula kako iz daljine dolazi neka lomljava... Bio je to nenadani poklon za mene.' ['The torrent came completely unexpectedly, all at once, while I was walking alongside a frozen river on Mount Zlatibor. Suddenly I heard some distant crashing sounds... It was an unexpected gift for me.'] (From the electronic conversation...)
} 
from the environment it immediately belongs to and transferred it into another context. First, she 'synchronized media-wise' the different contents from the realm of concrete sounds by conserving them using the appropriate equipment, and then she brought them over to the context of composing itself, using radio technology. In that context, i.e. during a particular technological treatment and compositional procedure, these acoustic materials inevitably changed their primary ambiance affiliation into an affiliation with a secondary ambiance, with the ambiance of organized sound, by becoming the means of its shaping and constituents of its irrevocable dramaturgical entity. That entity is, however, conceived to assume a repeated, retroactive attaching of these materials to their original context. But now, as the structural elements of a musical entity, they present it from the distance of their new primary affiliation, the affiliation to the radiophonic musical work. That is, they 'return' to their primary context from a different level: as materials which now do not belong inseparably to the concrete objects as the sources of their sound, but to the whole class of sources of a sound, irrespective of the particular space and time from which those sources originate. ${ }^{14}$ In that way, these materials become supratemporal and supraindividual..$^{15}$

This is exactly the reason why it is possible to use them as references to any specific place and historical time, and treat them also as petrified acoustic remnants of the past, as the results of an acoustic archaeology of sorts. Understood in that way, i.e. as specific archaeological findings, these materials provide us with a host of signposts to various interpretations and semantic constructs. Among other things, they are signposts towards the past as history 'on demand', which necessarily makes them a 'part' of what is chosen. But not as a reconstruction of historical fragments, rather as a personal expressive-meditative view to them. And possibly, as in this work, a view to some general fate of people living in our geopolitical boundaries, prompted by the associative field of Serbian history.

The field is suggested already by the title of the work: Metropola tisine / Stari Ras. Because the title implies at least three pieces of information pertaining to the direction of understanding and interpretation of the work. The first one is that Stari Ras was a capital; the second is that this capital no longer exists; the third is that this city, in spite of that, still exists somewhere in the silence / as the silence of the ruins, of their history, our knowledge about it and our encounters with it as a

\footnotetext{
${ }^{14}$ In that sense, for example, stomping and neighing are not only sounds produced by specific horses in a specific ambiance, which we may have happened to witness immediately and perpetuate in a recording: instead they are attached to a kind of acoustic representation, to the symbolization of horses in general, thus, they point to possible connotative meanings of their presence in various contexts.

15 The terms are used in Ingarden's sense.
} 
metropolis which, by its petrified traces, still undeniably brings its spirit to the ambiance where its authentic pulse stopped beating a long time ago.

And that pulse disappeared somewhere within the tumultuous and dramatic history of the rises and falls of the Serbian medieval state and Ras as its capital in the time of Stefan Nemanja and his heirs, as well as - since the last decade of the $12^{\text {th }}$ century - the diocese as the religious centre of the country at the time. ${ }^{16}$ The pulse also stopped in the walls of some of the most impressive edifices of Serbian art and culture, built in the central or broader area of medieval Ras, and where as pointed out - the composer gathered the authentic acoustic material.

Thus, whether they originate from the steep edge of a mountain cliff, from the outskirts of a village, from the very 'abyss' of history, from the mystery of the sunken river and the miracle-working monastery of Crna Reka, from the muteness and wisdom of weary stone and preserved artistic heritage, the collected sounds as archaeological remains and as a part of reality inspire the possible ways to the semantic reception of the work.

Of course, what is pertinent for various semantic individualizations are the types of compositional procedure which took the original samples away from their position of materials inseparable from the sources that produced them towards the dramaturgical position of functionalized acoustic signposts. Thus, the already described kinds of technological and compositional-technical treatment and modification, types of changes which, among other things, made the samples transform into one another, or into a musical flow which is not immediately designatory in a concrete but in the most general symbolic sense, already imply a certain initiative for notional interpretations.

In other words, both acoustic constancy, as well as acoustic mobility and changeability of the concrete acoustic materials have a semantic sense in this work exactly because these materials/samples, as symbols of a particular semantic content in our culture, basically 'inscribe' certain meanings in the musical flow. Therefore, the dramaturgy of the acoustic repetitions and changes of these samples is also the dramaturgy of their semantic positions. Thus, the acoustic impression of thunder in this composition does not remain at the level of representing a natural phenomenon, a sound which only sharply rends the air of the associated ambiance, but it becomes a sound which dully threatens that area by the violence of conflict and battle; therefore the sounds of work places and open spaces of village households grow coarsened to the vehemence of the elements which rout their land and

\footnotetext{
${ }^{16}$ Cf. Dragoslav Srejović, Miroslava Marinković, Jovan Kovačević et al., Istorija srpskog naroda. Prva knjiga. Od najstarijih vremena do Maričke bitke (1371) [History of Serbian People. Volume One. Since the Primeval Times to the Battle of Maritsa (1371)]. Belgrade, Srpska književna zadruga, 1981.
} 
flood it with blood; therefore the raindrops surrender their pastorality to the storm surge of fate, one of many seen by that ambiance.

This 'braid' of the past and the present which Ivana Stefanović realized in her Poem originated from her quiet creative meditation, induced by the silence of the absence of a whole world, but also by the silence of some latent, symbolic presence of the paths of its destiny. The author felt and perceived them already in the charge of the air, the tremors of the ground, the authenticity of the water power, i.e. in the basic elements of life fused with the environment of that quiet, vanished world. She identified it in her acoustic finds and, using them in a specific compositional procedure, she transposed it into the present.

Thus, that is a process and a space where extrovert narration and speech do not belong, where one communicates through silence. Where the latent, the possible in silence becomes more eloquent, semantically richer and further-reaching than the certainty and determination of speech. In other words, Ivana Stefanović in this composition bases her artistic communication upon the openness of the interpretative context instead the 'closeness' of text. The communication with what once was as what symbolically is today. But also with us - about it.

In the polyvalent space of silence.

Translated by Goran Kapetanović

\section{REFERENCES}

Englund, Peter, 'O istoriji tišine' ['Tystnadens historia'], in: Male istorije [Small Histories]. Edited and translated from Swedish by Ljubiša Rajić, Belgrade, Geopoetika, 2009.

Saville-Troike, Muriel, 'The Place of Silence in an Integrated Theory of Communication', in: Deborah Tannen and Muriel Saville-Troike (eds.), Perspectives on Silence, Norwood, New Jersey 07648, Ablex Publishing Corporation, 1995, 3-18.

Saville-Troike, Muriel, The Ethnography of Communication: An Introduction, Oxford, England, Basil Blackwell, 1982.

Srejović, Dragoslav, Miroslava Marinković, Jovan Kovačević et al., Istorija srpskog naroda. Prva knjiga. Od najstarijih vremena do Maričke bitke (1371) [History of Serbian People. Volume One. Since the Primeval Times to the Battle of Maritsa (1371)]. Belgrade, Srpska književna zadruga, 1981.

Veselinović-Hofman, Mirjana, 'Reflection on Silence', in: Tatjana Marković \& Vesna Mikić (eds.), (Auto)Biography as a Musicological Discourse, Belgrade, Department of Musicology - Faculty of Music, University of Arts in Belgrade, 2010, 256-265. 